\title{
Towards customer satisfaction and loyalty: What cuts it in a hair salon?
}

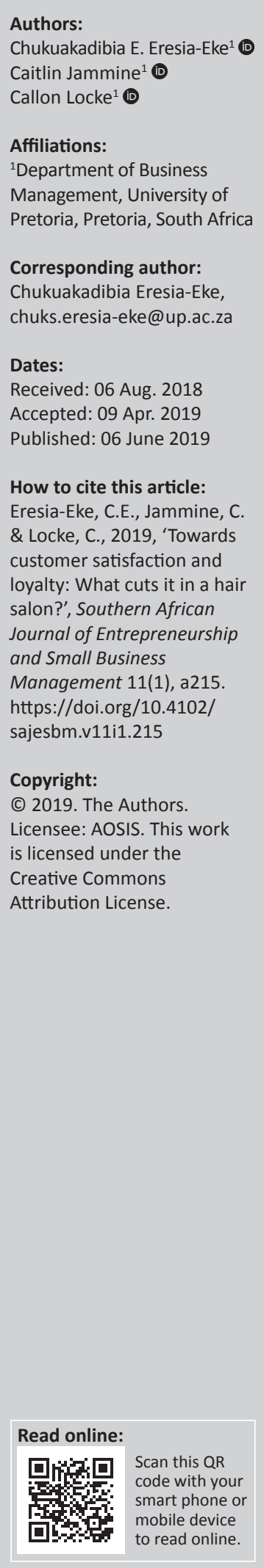

Background: The importance of customer loyalty, and customer satisfaction as well as patron's perceptions of service quality and value cannot be over-emphasised. Despite this, academic literature remains scant as it relates to possible relationships that could exist between these important variables within the hairdressing industry, although emerging entrepreneurs appear to find the hairdressing business attractive.

Objectives: The purpose of this study was to determine the existence and nature of the relationships between perceived value, perceived service quality, customer satisfaction and customer loyalty in hairdressing salons.

Method: The quantitative study was executed from a positivist philosophical position and employed a non-probability sampling method to select its respondents. The study utilised data that were collected from customers of hair salons in Pretoria, South Africa. Responses were obtained in a cross-sectional manner by relying on the central-location intercept survey technique. Descriptive and inferential statistical tools were utilised for the analysis of the data.

Results: The hypothesised relationships between the independent variables of customer satisfaction and perceived value and the dependent variable of customer loyalty were statistically significant and positive. A similar association was found between perceived service quality and perceived value as independent variables and customer satisfaction as the dependent variable. The study also revealed that perceived service quality correlates positively with perceived value.

Conclusion: These findings contribute to broadening the scope of academic discourse in the quality management and customer service domains, particularly from a South African perspective, and the identified relationships bear important practical implications for hair salon owners or managers.

Keywords: Customer loyalty; customer satisfaction; perceived value; service quality; hair salon.

\section{Introduction}

Intense competition within the service industry requires small businesses to create strong customer relationships and increase the value of the services they provide (Wei et al. 2013:6). This is because inability to do so would likely deflate the potential of a business to compete and possibly survive.

A situation where there is sparse value attached by customers to the service provided by a business can have unpalatable consequences for the business. Indeed, patronage could arise from the extent of value that a business creates for its customers. It can therefore be argued that the higher the value that a customer perceives to be getting from a service rendered, the higher the chances of repeat patronage. Customer loyalty will increase profitability and survival in the long run, decrease sales and marketing costs, increase opportunities for businesses to cross-sell services and provide positive word-of-mouth spread by the customers (Terblanche \& Boshoff 2010:1). Customer loyalty has become critical across the service industry and proves to be a valuable aspect of business. The hairdressing industry has evolved into a very competitive industry in both developed and developing economies, and thus has a substantial impact on these economies (Brookes \& Smith 2009; Picot-Lemasson et al. 2001). In spite of this, it is unknown how perceived service quality, perceived value and customer satisfaction predict customer loyalty within hair salons (Wei et al. 2013:4). 
Although the importance of customer loyalty has been realised by many businesses, it remains a difficult concept (Mittal \& Lassar 1998:177). In addition, many hair salons are started by small-scale or micro-entrepreneurs with little business knowledge and experience, which may therefore result in a weakened appreciation of certain factors that might contribute to a competitive advantage. It would seem rational to project that in order to achieve the outcomes associated with a competitive advantage, such as growth and profitability, securing customer loyalty could be essential. This study therefore explores the extent to which customer satisfaction and customer perceived value are related to customer loyalty. Furthermore, the study also interrogates the nature of the relationship, if any, between customer perceived value and perceived service quality and how each variable independent variable is linked with customer satisfaction in selected hair salons in Pretoria, South Africa.

Some impetus for the study is derived from the contention of Gallarza and Saura (2006:441) that the links between perceived service quality, perceived value and customer satisfaction have been found to be inconsistent across different industries. This argument emphasises the critical role of context in studies that could be examining perceived service quality and perceived value, customer satisfaction and customer loyalty. The importance of this is that results generated by studies are largely context specific and therefore a study like the current one can generate valuable insights that would enrich the literature related to the variables of interest. It is against this background that this study seeks to establish the existence or absence of relationships between the aforementioned variables in a selected sample of hair salons drawn from the previously unexplored hairdressing sector of South Africa's service industry.

In management literature, according to Wei et al. (2013:15), researchers opine that it is vital to shape a customer's perceptions of the service received because the overall experience created by businesses has a significant influence on perceptions of service quality, value and customer satisfaction, which ultimately influence customers' choice of service providers. Interestingly, about $50 \%$ of customers are likely to be loyal to a single business (Mittal \& Lassar 1998:178) despite the fact that loyalty is important and has implications for business performance and success. Consequently, there is a need for further understanding of loyalty by owners of hair salons because little research has been conducted on what contributes to customer loyalty in this industry (Wei et al. 2013:14).

\section{Literature review}

According to Terblanche and Boshoff (2010), customer loyalty is defined as a

deeply-held commitment to re-buy or re-patronise a preferred product or service consistently in the future, thereby causing repetitive purchasing, despite situational influences and marketing efforts having the potential to cause switching behaviour. (p. 2)
Loyal customers spend more money than those who are not loyal; they also show their loyalty to the business by increasing the spread of positive word-of-mouth and therefore are the most valuable group of customers to a business (Ganesh, Arnold \& Reynolds 2000:65).

Unfortunately, the literature on customer loyalty has been complicated by the lack of consensus and competing approaches with regard to the understanding of the term and the measurement of behavioural loyalty and attitudinal loyalty (Russell-Bennet, McColl-Kennedy \& Coote 2007:2). According to Dick and Basu (1994:100), loyalty consists of attitudinal and behavioural dimensions. Attitudinal loyalty considers a customer's particular commitment to a business and the intention to return, whereas behavioural loyalty considers patterns revealed through the spending behaviour of customers and ongoing patronage of the business (Russell-Bennet et al. 2007:5). From this, it is clear that most businesses would prefer for their customers' loyalty to be attitudinal in nature because of the emotional aspect involved (Terblanche \& Boshoff 2010:2). This is the background against which the issue of customer satisfaction, as a possible precursor of loyalty, becomes critical.

Rust and Oliver (1994:4) describe satisfaction as a process linked to the disconfirmation paradigm. This paradigm posits that customer satisfaction decisions are reached by comparing the performance of a product or service with the customers' expectations of the performance of the product or service. Karatepe (2011:290) identifies two perspectives of customer satisfaction. Firstly, customers who are satisfied make positive judgements about the quality of the service received. This is because the happier the customers feel (because of the positive experience), the more favourably they would rate the service quality. Secondly, positive perceptions about service quality can also precede customer satisfaction.

Notwithstanding this two-way causal order of the relationship between perceived service quality and customer satisfaction, Oliver (1981:27) views customer satisfaction as 'a psychological state resulting when the emotion surrounding disconfirmed expectations is coupled with the customer's prior feelings about the consumption experience'. In the light of this assertion, it would appear that satisfaction occurs because of a customer's feelings, expectations and state of mind with regard to a specific service experience. The importance that this holds for a business is linked to the fact that a focus on customer satisfaction presents a pathway to the maximisation of profits and has, according to Seth, Deshmukh and Vrat (2005:914), become recognised and adopted by businesses.

Interestingly, Green and Boshoff (2002:3) opine that in the tourism industry it is insufficient to explain customer satisfaction from a single encounter perspective. This position is supported by Bitner and Hubbert (1994:74), who argue that a customer's evaluation of a single service encounter does not necessarily represent the overall satisfaction that the 
customer has with the business, as it is necessary to take into consideration all service encounters. In essence, a customer's overall satisfaction is based on evaluations of multiple service encounters rather than a single encounter.

The study of Terblanche and Boshoff (2010) in the fast-food industry provides both supporting and contradicting evidence on the relationship between customer satisfaction and customer loyalty. Firstly, it was found that not all customer satisfaction necessarily leads to customer loyalty; secondly, it was found that even though the level of satisfaction among customers may be similar, their unique characteristics may cause customer loyalty to differ greatly; lastly, satisfaction may not be the best predictor of customer loyalty as other factors, such as trust, may need to be considered.

Against this background, it is apparent that some disharmony exists in the assessment of the role of customer satisfaction in the customer loyalty equation. This is exacerbated by the fact that customer satisfaction with a service is evaluative in nature as customers typically rely on expectations of the service, which are then compared with an evaluation of the customer's perceptions of what they received from the service and past experiences (Russell-Bennet et al. 2007:5).

Therefore, satisfaction, although largely subjective, may be a key driver of customer loyalty in a business context and could be considered as an antecedent of attitudinal loyalty. Although the situation in the specific context of a hair salon in South Africa remains unexplored, this study projects that:

$\mathbf{H}_{\mathbf{1}}$ : In hair salons, there is a positive relationship between customer satisfaction and customer loyalty.

Customer satisfaction consists of two determinants: perceived value and perceived quality (Fornell et al. 1996:9). There has been increased interest by scholars (Baker et al. 2002; Jensen 1996; Lin, Sher \& Shih 2005) in the notion of perceived value as new ideas and theoretical directions continue to emerge. Rust and Oliver (1994:7) assert that perceived value is what draws a customer towards or away from a potential competitor and that value can be specific to a certain encounter or can be seen as a more general and long-term perception of the entire business.

Notably, there has been a lack of consensus among researchers, customers and practitioners with regard to the meaning of value (Lai 1995:381). In three different studies by Holbrook (1994), Oh (1999) and Kumar and Grisaffe (2004), it was found that a number of different perspectives exist regarding customer perceptions of value. This is because customers do not necessarily purchase the best-quality service but rather make a purchase based on their own perceptions of the value of the service (Seth et al. 2005:933).

There are two methods to conceptualise the value construct, although Lin et al. (2005:319) argue that both methods are flawed. The first method views value as being onedimensional and measures the overall value perceptions of customers. This method is considerate of the trade-off between 'fair price', 'good value', 'value for money' and 'meeting quality and price requirements' (Baker et al. 2002:121; Sweeney, Soutar \& Johnson 1999:82). Although this is an effective and straightforward method, the complex nature of perceived value cannot be discerned using this one-dimensional method (Sweeney \& Soutar 2001:207). Therefore, a more appropriate measure is required to better understand customers' value perceptions. The second method views value as being multidimensional and measures the overall value perceptions of customers using give-dimensions (price) and take-dimensions (social, emotional and quality) as reflected in some multidimensional models, such as the PERVAL and SERV-PERVAL models (Lin et al. 2005:321-322).

Sweeney and Soutar (2001:216) developed the fourdimensional PERVAL model to assess the customer's perceived value of durable goods, which emphasised the importance of hedonic and utilitarian components: emotional value, social value, functional value because of quality, and functional value because of price. Subsequently, Petrick (2002:128) developed the SERV-PERVAL model to assess the perceived value of services based on the five dimensions of quality, emotional response, reputation, monetary price and behavioural price. These multidimensional models have helped researchers to discern the complex nature of customers' value perceptions.

However, in research conducted in the online retail industry, Lin et al. (2005:322) criticise these models as being incomplete and inconsistent with the definition of perceived value and argue that it should be conceptualised at an abstract level. To elucidate the nature of customer value, Green and Boshoff (2002:6) contend that inconsistency exists as it pertains to how and to what degree service quality contributes to customer's perception of value.

Zeithaml (1988:14) claims that quality and value are highly dissimilar constructs, with quality being a contributor to perceived value. However, perceived value does not depend solely on quality of service, but also on the context in which the buyer makes the evaluation of the service (Green \& Boshoff 2002:6). The predominant position in the literature is that value is placed at the heart of the modern approach to customers and is often related to customer loyalty (Gallarza \& Saura 2006:438). This is because customer loyalty is a function of customer value perception in the product and service industry such that as customer value increases, so too does customer loyalty (Mascarenhas, Kesavan \& Bernacchi 2006:400). Consequently, the study chooses to hypothesise that:

$\mathbf{H}_{2}$ : In hair salons, there is a positive relationship between customer perceptions of value and customer loyalty. 
An intervariable approach was investigated in the tourism industry by Gallarza and Saura (2006), who found that non-recognition of customer perceptions of value may result in lower customer satisfaction and consequently lower customer loyalty. This is in line with the findings of Oh (1999), who avers that in the hospitality industry, businesses need to consider customer value in order to increase service quality's power of prediction with regard to repurchase intentions. In deference to the findings of Gallarza and Saura (2006) to the effect that customer value perceptions could strengthen customer satisfaction, it is hypothesised that:

$\mathbf{H}_{3}$ : In hair salons, there is a positive correlation between customer perceptions of value and customer satisfaction.

There is a need for businesses to improve service quality in order to influence the behaviour of customers (Nimako et al. 2012:197). In the business world, service quality has become an essential requirement for businesses because of its significant impact on the performance of a business largely owing to its ability to lower costs and improve both customer satisfaction and customer loyalty (Seth et al. 2005:913). According to Ennew and Binks (1996:16), in the banking industry, service quality is a prime factor that contributes to a business's ability to achieve customer loyalty and, indeed, improved business performance.

The determination of service quality is often based on customers' comparison of expectations with their perceptions of the service performance (Duggal \& Verma 2013:139). This is why the understanding of customer perceptions of service experiences has always been critical to the success of businesses in the service industry (Mokhlis 2012:103). Khan and Tabassum (2010:35) found that customer satisfaction is a direct result of the quality of service that can further improve overall business performance.

This amplifies the need to explore in the specific case of the selected hair salons in South Africa the possible nexus between customer's perceived service quality and customer satisfaction; therefore, the study is swayed by the findings of Khan and Tabassum (2010) to hypothesise that:

$\mathbf{H}_{4}$ : In hair salons, there is a positive correlation between perceived service quality and customer satisfaction.

Businesses need to manage their internal quality capabilities which match a consistent external strategic focus that identifies with how customers perceive value (Woodruff 1997:140). Although Green and Boshoff (2002:6) contend that while service quality is vital to the concept of service value, it is not the only contributor, nor does the presence of service quality imply the presence of service value, and vice versa.

Therefore, perceived value does not only depend on the quality of the service that is received, but also on the context in which the customer makes an evaluation. The implication of this is that it will be problematic to rely on results from studies in a different context to determine with any measure of precision what is likely to be the case in the hair salons that participated in the current study, for instance.

Oh (1999:78) found that customer value is an important construct to consider when investigating service quality and customer satisfaction, and vice versa. Competition based on customer value perceptions will simultaneously complement and move beyond the focus on quality management (Woodruff 1997:151).

From a customer-oriented perspective, value can be described as a function of perceived service quality, and it has been suggested that quality is the most influential dimension of customer value perceptions (Green \& Boshoff 2002:6) and as this appears logical, this study leans on the position to hypothesise that:

$\mathbf{H}_{5}$ : In hair salons, perceived service quality is positively associated with perceived value.

\section{Methodology}

This study is a quantitative research effort. As with most quantitative studies, the ontological philosophical perspective that there is an objective truth is adopted. This standpoint meant that in the execution of the study, the researchers had to be near-passive observers rather than active participants in the creation of meaning associated with the constructs of interest.

The target population consisted of the customers of hair salons in Pretoria, South Africa. As the study focuses on customer loyalty, customer satisfaction, perceived service quality and perceived value in the context of hair salons, the units of analysis are the individual customers. In pursuit of adequate demographic diversity in the study, an effort was made to ensure representation of men and women, as well as races, as best as possible. As there was no accurate sampling frame available from which to draw a probability sample, this study made use of a non-probability sampling method, allowing selection at the discretion of the researcher (Saunders, Lewis \& Thornhill 2012:281). Effectively, 180 valid questionnaires were collected from respondents, approached on the basis of the central-location intercept survey method. The respondents were approached at the hair salons where the customers received the service.

The instrument for data collection was a questionnaire constructed with previously validated scales. A 17-item SERVQUAL scale developed by Parasuraman, Zeithaml and Berry (1988) was utilised for the measurement of perceived service quality. Similarly, a three-item scale developed by Edward and Sahadev (2011) and a four-item scale developed by Wang (2010) were utilised to measure perceived value and customer loyalty, respectively, while a single item was utilised to gauge customer satisfaction. All items in the scales were made of statements accompanied by Likert-style seven-point options ranging from 1 (strongly disagree) to 7 (strongly agree). Although the scales utilised had been validated and deemed appropriate for use in previous 
studies, they were nonetheless examined for reliability. The associated Cronbach's alphas for the perceived service quality, perceived value and customer loyalty scales were $0.87,0.83$ and 0.81 , respectively.

These values suggest acceptable levels of internal consistency and, consequently, reliability. The responses obtained for each scale were then averaged to provide an overall score for the construct of interest.

\section{Ethical consideration}

Ethical clearance was obtained from the University of Pretoria (Ethical clearance number: u14213754_u14019672/2017).

\section{Results}

Table 1 provides the demographic profile of the 180 customers who took part in this study. Of the total sample, 114 respondents were women $(63.3 \%)$ and 66 were men $(36.7 \%)$. This is possibly an indication that a larger number of women make use of the services of hair salons in comparison to their male counterparts. In addition, the number of respondents belonging to black and white races was fairly balanced, with the percentage of black people being $38.5 \%$ and that of white people being 38\%. Mixed-race people (7) and 'other' (29) racial groups had the smallest number of respondents compared to black (65) and white (79) race groups.

The study also sought to determine average scores across the respondent population for questionnaire items as well as the study's constructs. Based on the results in Table 2, the statements the employees of this hair salon are always willing to help customers' and 'employees of this hair salon are well mannered' had the highest mean values of 6.54 (standard deviation [SD] 0.62) and 6.53 (SD 0.66), respectively. Of all the items, these two items had the lowest SD, which suggests that responses to these items had the least variation and were skewed towards 'agree' or 'strongly agree'. The statement 'the hair salon is visually attractive' had the lowest mean of 6.08 (SD 0.94). This suggests that the average respondent 'slightly agrees' or 'agrees' with the statement. The corresponding SD for this statement has a relatively high value in relation to the other statements, suggesting a higher variance in responses to this statement.

For the perceived value construct, the statement 'comparing what I pay for the service I receive, the hair salon provides good value to me' had the highest mean value of 6.34 .

TABLE 1: Demographic profile of the respondents.

\begin{tabular}{llcccccc}
\hline Gender & Variable & \multicolumn{4}{c}{ Ethnic groups } & \multirow{2}{*}{ Total } \\
\cline { 3 - 6 } & & $\begin{array}{c}\text { Black } \\
\text { people }\end{array}$ & $\begin{array}{c}\text { White } \\
\text { people }\end{array}$ & $\begin{array}{c}\text { Mixed-race } \\
\text { people }\end{array}$ & Other \\
\hline \multirow{2}{*}{ Male } & Count & 25 & 30 & 1 & 10 & 66 \\
& $\%$ within ethnic groups & 38.5 & 38.0 & 14.3 & 34.5 & 36.7 \\
\multirow{2}{*}{ Female } & Count & 40 & 49 & 6 & 19 & 114 \\
& \% within ethnic groups & 61.5 & 62.0 & 85.7 & 65.5 & 63.3 \\
\hline \multirow{2}{*}{ Total } & Count & $\mathbf{6 5}$ & $\mathbf{7 9}$ & $\mathbf{7}$ & $\mathbf{2 9}$ & $\mathbf{1 8 0}$ \\
\cline { 2 - 6 } & \% within ethnic groups & $\mathbf{1 0 0 . 0}$ & $\mathbf{1 0 0 . 0}$ & $\mathbf{1 0 0 . 0}$ & $\mathbf{1 0 0 . 0}$ & $\mathbf{1 0 0 . 0}$ \\
\hline
\end{tabular}

The lowest mean of 6.16 corresponding with the statement 'this hair salon charges a reasonable price for the service it provides' suggests that respondents agreed with the statement. The SD (0.75) of the responses to this statement indicates a low variation of responses. In relation to the construct of customer loyalty, results presented in Table 2 suggest that the statement 'I will return to this hair salon more in the next few years' had the highest mean value of 6.40 $(\mathrm{SD}=0.77)$, while the lowest mean of $6.17(\mathrm{SD}=1.06)$ is linked to the statement 'I have recommended this hair salon to people who seek my advice'. Nonetheless, the responses provided are clearly skewed towards the options 'slightly agree' to 'agree'.

At the construct level, the results suggest that perceived service quality of hair salons is positive given the overall mean score of 6.33 (SD = 0.79). Similarly, the determined construct mean scores for perceived value, customer loyalty and customer satisfaction were positive in terms of their respective average scores of $6.26(\mathrm{SD}=0.74), 6.28(\mathrm{SD}=0.95)$ and $6.43(\mathrm{SD}=0.81)$.

All variables considered in the hypotheses were measured at an interval level, but it was nonetheless necessary to

TABLE 2: The mean and standard deviation for questionnaire items.

\begin{tabular}{|c|c|c|}
\hline Item & Mean & $\begin{array}{l}\text { Standard } \\
\text { deviation }\end{array}$ \\
\hline \multicolumn{3}{|l|}{ Service quality } \\
\hline This hair salon has up-to-date equipment. & 6.17 & 0.87 \\
\hline This hair salon is visually attractive. & 6.08 & 0.94 \\
\hline This hair salon's employees are neat and well dressed. & 6.25 & 0.86 \\
\hline $\begin{array}{l}\text { When I make a complaint, the hair salon is sympathetic and } \\
\text { reassuring. }\end{array}$ & 6.17 & 0.97 \\
\hline $\begin{array}{l}\text { The appearance of the hair salon is what a hair salon should } \\
\text { look like. }\end{array}$ & 6.26 & 0.88 \\
\hline This hair salon is reliable. & 6.42 & 0.77 \\
\hline $\begin{array}{l}\text { This hair salon provides its services at the time it promises to } \\
\text { do so. }\end{array}$ & 6.42 & 0.73 \\
\hline $\begin{array}{l}\text { This hair salon tells customers exactly when services will be } \\
\text { performed. }\end{array}$ & 6.14 & 1.10 \\
\hline I receive immediate service from this hair salon's employees. & 6.37 & 0.68 \\
\hline Employees of this hair salon are always willing to help customers. & 6.54 & 0.62 \\
\hline $\begin{array}{l}\text { Employees of this hair salon make time to respond to } \\
\text { customer requests. }\end{array}$ & 6.42 & 0.68 \\
\hline I can trust employees of this hair salon. & 6.44 & 0.81 \\
\hline Employees of this hair salon are well mannered. & 6.53 & 0.66 \\
\hline Employees of this hair salon give me personal attention. & 6.48 & 0.69 \\
\hline Employees of this hair salon know what my needs are. & 6.22 & 0.76 \\
\hline This hair salon has my best interests at heart. & 6.29 & 0.75 \\
\hline This hair salon has convenient operating hours. & 6.40 & 0.71 \\
\hline \multicolumn{3}{|l|}{ Perceived value } \\
\hline $\begin{array}{l}\text { Comparing what I pay for the service I receive, the hair salon } \\
\text { provides good value to me. }\end{array}$ & 6.34 & 0.71 \\
\hline This hair salon's service is good value for money. & 6.28 & 0.75 \\
\hline $\begin{array}{l}\text { This hair salon charges a reasonable price for the service it } \\
\text { provides. }\end{array}$ & 6.16 & 0.75 \\
\hline \multicolumn{3}{|l|}{ Customer loyalty } \\
\hline $\begin{array}{l}\text { I consider this hair salon as my first choice for hairstyling or } \\
\text { barber services. }\end{array}$ & 6.27 & 0.94 \\
\hline I will return to this hair salon more in the next few years. & 6.40 & 0.77 \\
\hline I have said positive things about this hair salon to other people. & 6.27 & 1.03 \\
\hline $\begin{array}{l}\text { I have recommended this hair salon to people who seek my } \\
\text { advice. }\end{array}$ & 6.17 & 1.06 \\
\hline \multicolumn{3}{|l|}{ Customer satisfaction } \\
\hline I am satisfied with the services that I receive from this hair salon. & 6.43 & 0.81 \\
\hline
\end{tabular}


investigate if associated data distributions satisfy the conditions of normality and linearity required for the conduct of parametric significance tests. Table 3 reports the results of the normality tests with regard to the focal constructs of this study. The Kolmogorov-Smirnov statistical test was utilised to examine the normality of the distribution of data linked to the constructs of perceived service quality, perceived value, customer loyalty and customer satisfaction.

All $p$-values of the Kolmogorov-Smirnov test are less than the level of significance (0.05), indicating that a normal bell-shaped distribution does not exist for any of the constructs. Thus, the assumption of normality is not satisfied for any of the constructs investigated in this study. Consequently, Spearman's rank-order correlation test (non-parametric significance test) was utilised to test the study's hypothesised relationships.

The stated hypotheses are directional and are tested at a 5\% level of significance $(\alpha=0.05)$ and the results are presented in Table 4 .

The study hypothesised that a positive relationship exists between customer satisfaction and customer loyalty in hair salons $\left(\mathrm{H}_{1}\right)$. The results of Spearman's rank-order correlation test reveal a $p$-value of 0.000 , which is smaller than the level of significance $(\alpha=0.05)$ and so this indicates that there is a statistically significant correlation between customer satisfaction and customer loyalty in hair salons. The correlation coefficient of 0.541 suggests that the magnitude of the correlation is moderate. Consequently, hypothesis $\mathrm{H}_{1}$ is accepted. The results of the same test for the four other hypotheses investigated by the study returned $p$-values of less than 0.05 , which implies the existence of statistically significant correlations between the independent and dependent variables considered in $\mathrm{H}_{2}, \mathrm{H}_{3}, \mathrm{H}_{4}$ and $\mathrm{H}_{5}$. Therefore, these results lead the study to accept the five

TABLE 3: Results of tests of normality.

\begin{tabular}{lccc}
\hline Variable & \multicolumn{3}{c}{ Kolmogorov-Smirnov test $\dagger$} \\
\cline { 2 - 4 } & Statistic & $\boldsymbol{d f}$ & $\boldsymbol{p}$ \\
\hline Service quality & 0.095 & 180 & 0.000 \\
Perceived value & 0.154 & 180 & 0.000 \\
Customer loyalty & 0.173 & 180 & 0.000 \\
Customer satisfaction & 0.331 & 180 & 0.000
\end{tabular}

$d f$, Degrees of freedom

$\dagger$, Lilliefors significance correction.

TABLE 4: Results of hypothesis tests.

\begin{tabular}{llcccc}
\hline $\begin{array}{l}\text { Spearman's } \\
\text { rho }\end{array}$ & Variable & $\begin{array}{c}\text { Customer } \\
\text { satisfaction }\end{array}$ & $\begin{array}{c}\text { Service } \\
\text { quality }\end{array}$ & $\begin{array}{c}\text { Perceived } \\
\text { value }\end{array}$ & $\begin{array}{c}\text { Customer } \\
\text { loyalty }\end{array}$ \\
\hline $\begin{array}{llccc}\text { Customer } \\
\text { satisfaction }\end{array}$ & Correlation coefficient & 1.000 & 0.567 & 0.366 & 0.541 \\
& Significance (1-tailed) & - & 0.000 & 0.000 & 0.000 \\
$\begin{array}{l}\text { Perceived } \\
\text { service Quality }\end{array}$ & Correlation coefficient & 0.567 & 1.000 & 0.471 & 0.579 \\
\cline { 2 - 6 } $\begin{array}{l}\text { Perceived } \\
\text { value }\end{array}$ & Significance (1-tailed) & 0.000 & - & 0.000 & 0.000 \\
Customer & Correlation coefficient & 0.366 & 0.471 & 1.000 & 0.559 \\
loyalty & Significance (1-tailed) & 0.000 & 0.000 & - & 0.000 \\
& Correlation coefficient & 0.541 & 0.579 & 0.559 & 1.000 \\
\hline & Significance (1-tailed) & 0.000 & 0.000 & 0.000 & - \\
\hline & $\mathrm{N}$ & 180 & 180 & 180 & 180 \\
\hline
\end{tabular}

hypotheses stated and tested in the study. However, while all the determined relationships were of a positive nature, they differed in terms of their strengths of association.

The association between perceived value and customer loyalty $(r=0.559)$ is moderate. The realised $r$-value of 0.567 is indicative of a moderate correlation between perceived service quality and customer satisfaction. For the hypothesised association between perceived value and customer satisfaction, the result of $r=0.366$ points to a positive but weak relationship, while the magnitude of the correlation (0.471) between perceived service quality and perceived value is also weak.

\section{Discussion}

The purpose of this empirical study was to examine the possible links between customer satisfaction, perceived value, perceived service quality and customer loyalty in the context of hair salons in Pretoria, South Africa. The study results indicate that there is indeed a relationship between perceived service quality, customer satisfaction, perceived value and customer loyalty. The findings suggest that if customers perceive the service quality to be high or if their perceived value of the service is high, it will coincide with high customer satisfaction. Furthermore, the results also suggest that high customer satisfaction correlates with customer loyalty in the studied hair salons. These results are in line with the findings of studies undertaken by Gallarza and Saura (2006), Ennew and Binks (1996), Kumar, Kee and Manshor (2009) and Khan and Tabassum (2010), although within different contexts. Notably, however, they contradict Mittal and Lassar's (1998) finding that customer satisfaction does not correlate with customer loyalty.

The study's findings suggest that it may be worthwhile for hair salons to consider investing some effort towards improving service quality perceptions and value perceptions as these correlate with the desirable outcomes of customer satisfaction and customer loyalty. In this regard, especially as it concerns service quality, hair salons may wish to consider training employees, creating a more professional and conducive environment and emphasising improvements in current levels of responsiveness, empathy, reliability, assurance and tangibles. Hair salons could also focus on making the customer experience worthwhile as this lends itself to improved levels of perceived value. Practically, this can be achieved by providing high-quality service at an affordable price.

\section{Conclusion}

It is instructive to note, as a study limitation, that given the use of a non-probability sampling method, there is no guarantee that the study sample is an accurate representation of a larger target population, especially with regard to the demographic considerations of gender and race. Moreover, the findings of the study are technically not generalisable and apply more appropriately within the cohort of studied 
hair salons. The high level of satisfaction with the hair salons reflected in the data collected for the study could be consistent with the fact that the study's sample may have been dominated by repeat or loyal customers and this needs to be noted as a possible study limitation, largely because of its potential biased effect on the study's results.

Future research in this field could possibly benefit from conducting the research in a larger geographic area and on a larger respondent group created through a probability sampling technique, thereby making the findings more generalisable across a larger population. To achieve more accurate data collection, screening questions should be added to the questionnaire in order to identify first-time and repeat customers of hair salons as this would enable the undertaking of a comparative analysis of the perceptions of these two groups of customers.

\section{Acknowledgements Competing interests}

The authors have declared that no competing interests exist. The views and opinions expressed in this article are those of the authors and do not necessarily reflect the official policy or position of any affiliated agency of the authors

\section{Authors' contributions}

C.E-E. was responsible for the methodology, research guidance and write-up of the article. C.J. and C.L. contributed to the literature review, data analysis and write-up of the article.

\section{References}

Baker, J., Parasuraman, A., Grewal, D. \& Voss, G., 2002, 'The influence of multiple store environment cues on perceived merchandise value and patronage intentions', Journal of Marketing 66(2), 120-141. https://doi.org/10.1509/jmkg.66.2.120.18470

Bitner, M. \& Hubbert, A., 1994, 'Encounter satisfaction versus overall satisfaction versus quality: The customer's voice', in R.T. Rust \& R.L. Oliver (eds.), Service quality: New directions in theory and practice, pp. 72-94, Sage Publications, Inc, Thousand Oaks, CA.

Brookes, B. \& Smith, C., 2009, 'Technology and gender: Barbers and hairdressers in New Zealand', History and Technology 25(4), 365-386. https://doi.org/10.1080/ 07341510903313055

Dick, A. \& Basu, K., 1994, 'Customer loyalty towards an integrated framework', Journal of the Academy of Marketing Science 22(2), 99-113. https://doi.org/10.1177/ 0092070394222001

Duggal, E. \& Verma, H., 2013, 'Service quality: Construct comprehension and evolution over time', Journal of Services Research 13(1), 135-160.

Edward, M. \& Sahadev, S., 2011, 'Role of switching costs in the service quality, perceived value, customer satisfaction and customer retention linkage', Asia Pacific Journal of Marketing and Logistics 23(3), 327-345. https://doi.org/ $10.1108 / 13555851111143240$

Ennew, C. \& Binks, M., 1996, 'The impact of service quality and service characteristics on customer retention: Small businesses and their banks in the UK', British Journal of Management 7(3), 219-230. https://doi.org/10.1111/j.1467-8551.1996.tb00116.x

Fornell, C., Johnson, M., Anderson, E., Cha, J. \& Bryant, B., 1996, 'The American customer satisfaction index: Nature, purpose, and findings', Journal of Marketing 60(4), 7-18. https://doi.org/10.2307/1251898

Gallarza, M. \& Saura, I., 2006, 'Value dimensions, perceived value, satisfaction and loyalty: An investigation of university students' travel behaviour', Tourism Management 27(3), 437-452. https://doi.org/10.1016/j.tourman.2004.12.002

Ganesh, J., Arnold, M. \& Reynolds, K., 2000, 'Understanding the customer base of service providers: An examination of the difference between switchers and stayers', Journal of Marketing 64(2), 65-87. https://doi.org/10.1509/jmkg.64.3.65.18028

Green, S. \& Boshoff, C., 2002, 'An empirical assessment of the relationships between service quality, satisfaction and value: A tourism study', Management Dynamics 11(3), 2-16.
Holbrook, M., 1994, 'The nature of customer value: An axiology of services in the consumption experience', in R.T. Rust \& R.L. Oliver (eds.), Service quality: New consumption experience, in R.T. Rust \& R.L. Oliver (eds.), Service quality: New
directions in theory and practice, pp. 21-71, Sage Publications, Inc, Thousand directions
Oaks, CA.

Jensen, H., 1996, 'The interrelationship between customer and customer value', Asia Pacific Advances in Customer Research 2(1), 60-63.

Karatepe, O., 2011, 'Service quality, customer satisfaction and loyalty: The moderating role of gender', Journal of Business Economics and Management 12(2), 278-300. https://doi.org/10.3846/16111699.2011.573308

Khan, P. \& Tabassum, A., 2010, 'Service quality and customer satisfaction of the beauty-care service industry in Dhaka: A study on high-end women's parlours', The Journal of Business in Developing Nations 12(1), 32-58.

Kumar, A. \& Grisaffe, D., 2004, 'Effects of extrinsic attributes on perceived quality, customer value, and behavioural intentions in B2B settings: A comparison across goods and services industries', Journal of Business-to-Business Marketing 11(4), 43-74. https://doi.org/10.1300/J033v11n04_03

Kumar, M., Kee, F. \& Manshor, A., 2009, 'Determining the relative importance of critical factors in delivering service quality of banks: An application of dominance analysis in SERVQUAL model', Managing Service Quality 19(2), 211-228. https:// doi.org/10.1108/09604520910943198

Lai, A., 1995, 'Customer values, product benefits and customer value: A consumption behaviour approach', Advances in Customer Research 22(1), 381-388.

Lin, C., Sher, P. \& Shih, H., 2005, 'Past progress and future directions in conceptualizing customer perceived value', International Journal of Service Industry Management 16(4), 318-336. https://doi.org/10.1108/09564230510613988

Mascarenhas, O., Kesavan, R. \& Bernacchi, M., 2006, 'Lasting customer loyalty: A total customer experience approach', Journal of Customer Marketing 23(7), 397-405. https://doi.org/10.1108/07363760610712939

Mittal, B. \& Lassar, W., 1998, 'Why do customers switch? The dynamics of satisfaction versus loyalty', Journal of Services Marketing 12(3), 177-194. https://doi.org/ 10.1108/08876049810219502

Mokhlis, S., 2012, 'The influence of service quality on satisfaction: A gender comparison', Public Administration Research 1(1), 103-112. https://doi.org/ 10.5539/par.v1n1p103

Nimako, S., Azumah, F., Donkor, F. \& Adu-Brobbey, V., 2012, 'Confirmatory factor analysis of service quality dimensions within mobile telephony industry in Ghana', Electronic Journal of Information Systems Evaluation 15(2), 197-215.

Oh, H., 1999, 'Service quality, customer satisfaction, and customer value: A holistic perspective', International Journal of Hospitality Management 18(1), 67-82. https://doi.org/10.1016/S0278-4319(98)00047-4

Oliver, R., 1981, 'Measurement and evaluation of satisfaction processes in retai settings', Journal of Retailing 57(3), 25-48.

Parasuraman, A., Zeithaml, V. \& Berry, L., 1988, 'SERVQUAL: A multiple-item scale for measuring customer perceptions of service quality', Journal of Retailing 64(1), $12-40$.

Petrick, J., 2002, 'Development of a multi-dimensional scale for measuring the perceived value of a service', Journal of Leisure Research 34(2), 119-134. https:// doi.org/10.1080/00222216.2002.11949965

Picot-Lemasson, A., Decocq, G., Aghassian, F. \& Leveque, J., 2001, 'Influence of hairdressing on the psychological mood of women', International Journal of
Cosmetic Science 23(3), 161-164. https://doi.org/10.1046/j.1467-2494.2001. Cosmetic

Russell-Bennet, R., McColl-Kennedy, J. \& Coote, L., 2007, 'Involvement, satisfaction and brand loyalty in a small business services setting', Journal of Business Research 60(12), 1253-1260. https://doi.org/10.1016/j.jbusres.2007.05.001

Rust, R. \& Oliver, R., 1994, 'Service quality: Insights and managerial implications from the frontier', in R.T. Rust \& R.L. Oliver (eds.), Service quality: New directions in theory and practice, pp. 1-19, Sage Publications, Inc, Thousand Oaks, CA.

Saunders, M., Lewis, P. \& Thornhill, A., 2012, Research methods for business students, 6 th edn., Pearson, Harlow, UK.

Seth, N., Deshmukh, S. \& Vrat, P., 2005, 'Service quality models: A review', Internationa Journal of Quality and Reliability Management 22(9), 913-949. https://doi.org/ 10.1108/02656710510625211

Sweeney, J. \& Soutar, G., 2001, 'Customer perceived value: The development of a multiple item scale', Journal of Retailing 77(2), 203-220. https://doi.org/10.1016/ S0022-4359(01)00041-0

Sweeney, J., Soutar, G. \& Johnson, L., 1999, 'The role of perceived risk in the qualityvalue relationship: A study in a retail environment', Journal of Retailing 75(1), 77-105. https://doi.org/10.1016/S0022-4359(99)80005-0

Terblanche, N. \& Boshoff, C., 2010, 'Quality, value, satisfaction and loyalty amongst race groups: A study of customers in the South African fast food industry', South African Journal of Business Management 41(1), 1-9.

Wang, C., 2010, 'Service quality, perceived value, corporate image, and customer loyalty in the context of varying levels of switching costs', Psychology and Marketing 27(3), 52-262. https://doi.org/10.1002/mar.20330

Wei, J., Lee, M., Chen, H. \& Wu, H., 2013, 'Customer relationship management in the hairdressing industry: An application of data mining techniques', Expert System with Applications 40(17), 1-27. https://doi.org/10.1016/j.eswa.2013.07.053

Woodruff, R., 1997, 'Customer value: The next source for competitive advantage', Academy of Marketing Science Journal 25(2), 139-153. https://doi.org/10.1007/ BF02894350

Zeithaml, V., 1988, 'Customer perceptions of price, quality, and value: A means-end model and synthesis of evidence', Journal of Marketing 52(3), 2-22. https://doi. org/10.1177/002224298805200302 